\title{
Life cycle assessment of opencast lignite mining
}

\author{
Lukasz Lelek $^{1}$ (D) Joanna Kulczycka ${ }^{2}$
}

Received: 20 November 2020/Revised: 20 May 2021 / Accepted: 10 October 2021 / Published online: 19 November 2021

(C) The Author(s) 2021

\begin{abstract}
The life cycle phase of fossil fuel extraction is mainly considered in the life cycle assessment (LCA) when evaluating the energy production processes. It is then only one of many unit processes, which contribute to the blurring of mining-relevant results. There are few items in the literature focusing exclusively on the lignite mining phase and analysing the specific mining conditions and associated environmental impacts. The article focuses on the LCA of lignite mining processes on the basis of data coming from a Polish mine. The technology for opencast lignite mining is noted for its high production efficiency, high level of recovery and lower risk as regards the safety of workers when compared with underground mining systems. However, the need to remove large amounts of overburden to uncover the deposit contributes to a much greater degradation of the landscape. Analysing the results obtained, several key (hot spot) elements of the lignite mining operations were distinguished for modelling the environmental impact, i.e.: calorific value, the amount of electricity consumption, the manner in which waste and overburden are managed. As a result there is a high sensitivity of the final indicator to changes in these impacts.
\end{abstract}

Keywords Life cycle assessment (LCA) $\cdot$ Lignite $\cdot$ Mining $\cdot$ Fossil fuel

\section{Introduction}

The EU's climate policy, including the European Green Deal announced in 2019, is intended to achieve climate neutrality for the continent. This is mainly to be achieved through the transformation of the energy sector by reducing the burning of fossil fuels and moving towards a net-zero emissions strategy (The European Parliament 2019) by supporting the development of renewable energy sources together with energy storage e.g. using hydrogen, $\mathrm{CO}_{2}$

Lukasz Lelek

lelek@meeri.pl

1 Mineral and Energy Economy Research Institute, Polish Academy of Sciences, Wybickiego 7A Str., 31-261 Cracow, Poland

2 Faculty of Management, AGH University of Science and Technology, 30-067 Cracow, Poland offsetting, sustainable production and consumption practices ( European Commission 2020), etc.

EU has a significantly lower emissions intensity of power generation than other large economies. The carbon intensity was 270 grammes of $\mathrm{CO}_{2}$ per kilowatt-hour $\left(\mathrm{g} \mathrm{CO}_{2} / \mathrm{kW} \mathrm{h}\right)$ in 2018 , compared with over $400 \mathrm{~g} \mathrm{CO}_{2} /$ $\mathrm{kW} \mathrm{h}$ in the United States, over $500 \mathrm{~g} \mathrm{CO}_{2} / \mathrm{kW}$ h in Japan, around $600 \mathrm{~g} \mathrm{CO}_{2} / \mathrm{kW} \mathrm{h}$ in the People's Republic of China and over $700 \mathrm{~g} \mathrm{CO}_{2} / \mathrm{kW} \mathrm{h}$ in India and Australia (IEA 2020). Therefore, fossil fuels such as coal still constitute a significant source of energy in the world and in the EU. Coal consumption in the EU has fallen by $34 \%$ since 1995 and production by $53 \%$. Dependence on coal imports, however, has increased to $40 \%$ with $30 \%$ of this demand coming from Russia, even though the share of coal in the EU energy mix has decreased to $15 \%$. There are several factors affecting the future use of coal, these undoubtedly including climate considerations, but also security of supply. This factor has contributed to a reduction in coal use in 
some import-dependent countries which rely on this resource, but coal also provides energy security for those countries with their own resources like Poland. It should be pointed out that the Lisbon Treaty allows each Member State to decide on its energy mix. The European Council therefore recognises the need to ensure energy security and respect the right of Member States to decide on their energy mix and to choose the most appropriate technologies (Council of the European Union 2020). The recent announcements of a gradual phasing out of coal-fired power plants are expected to lead to a further reduction in demand for coal, which will affect the development of other energy carriers such as gas, renewable or nuclear. The "Coal Regions in Transition" platform (European Commission 2017) and dedicated policy instruments are expected to contribute to mitigating the social impact, especially for European regions associated with coal mining activities and therefore the transformation of coal-dependent regions will probably take several decades as coalfired power plant still provides a high share of global capacity-38\% in 2019 (IEA 2019). Analysing various scenarios prepared by the IEA (International Energy Agency) for the development of the energy sector until 2040, it can be seen that this share will decrease. However, under different scenarios it may still remain at a significant level of 25\% (Stated Policies 2040 Scenario) or will be greatly reduced to $4 \%$ (Sustainable Development 2040 Scenario).

In the case of lignite, global consumption in 2018 was 793.5 million tonnes, with total demand for coal (brown, hard and coking coal) amounting to 5458 million tonnes (IEA 2019). In Poland, its share in electricity production in 2019 was $24.5 \%$ (41.5 TW h) which was $15 \%$ less than in 2018. This was associated, as in the global market, with a general decline in energy production (3.9\%), with historically the lowest share of energy generated from coal in the domestic energy mix (74\%) as well as the highest import of energy (10.6 TW h). This situation is mainly due to the increase in labour costs, lower quality of the fuel extracted (average calorific value below 7.9 $\mathrm{MJ} / \mathrm{kg}$ ) and high charges for $\mathrm{CO}_{2}$ emissions. These aspects translate into a decrease in the competitiveness of energy from coal in relation to other sources, including renewable ones.

In 2017, there were five opencast mines operating in Poland that supply fuel to five power plants. These mines were: Adamów, Belchatow, Konin, Turow and Sieniawa. Their total output in 2017 reached more than 61 million $\mathrm{Mg}$ of coal, with PGE GiEK S.A. KWB Belchaotw Branch being the largest producer, with output at $70 \%$ of domestic production. The total occupation area within the boundaries of this mine's includes:
(1) field Belchatow-1518 ha, with internal overburden dump-1755 ha,

(2) field Szczercow-1415 ha, with external overburden dump-1061 ha,

(3) Rogowiec support facility-212 ha,

(4) Chabielice support facility-72 ha.

The share in the domestic lignite production of other companies in 2017 was as follows:

(1) PAK KWB Konin S.A. at 14,

(2) PGE GiEK S.A. KWB Turow 11,

(3) PAK KWB Adamow S.A. 5,

(4) Kopalnia Wegla Brunatnego Sieniawa Sp. z o.o. (about 100 thousand $\mathrm{Mg}$ ).

Documented resources are being depleted in currently exploited deposits, In the currently exploited deposits documented resources are being exhausted and opening new deposits for exploitation meets with strong opposition of local communities due to transformation of landscape and hydrological system. Forecasts predict that after 2030 there will be a drastic decrease in lignite mining, and in 2050 its exploitation may stop altogether.

According to the current draft of the Energy Policy for Poland until 2040, it is predicted that in the next 10 years the share of coal in the production of electricity will drop to about $60 \%$. Therefore, it is imperative to explore new theories and technologies that ensure high safety, low environmental pollution, and low damaging impact during coal mining (Ju et al. 2009). Moreover, it is crucial to analyse the impact during the whole life cycle. The literature review (Guimarães da Silva et al. 2018) shows that there is a lack of modelling of the impact of mining processes based on the LCA methodology which also takes into account the quality of the fuel obtained. Even though Poland is one of the largest producers of coal in the EU, LCA and holistic assessment is still relatively rare (Burchart-Korol et al. 2016; Kopacz et al. 2017). The items available underline some methodological inconsistencies, which may be the reason for the small number of LCA studies undertaken in the mining industry. These include, problems with the selection of an appropriate functional unit, the limits of the system analysed or the determination of the weight of particular impact categories reflecting significant environmental problems in mining. Some of the cases in the literature (Wang and Mu 2014; Yu et al. 2014; Xu 2013; Aguirre-Villegas and Benson 2017) indicate that the environmental burdens obtained from the calculation of the LCA for the coal consumption and energy production system cannot be regarded as informative indicator scores since they do not provide a means for practical decisionmaking in terms of performance (neither negative nor positive). This lack of informative indicator scores makes it 
difficult for industrial practitioners to make sense of the environmental burdens (results of a traditional LCA study) according to the values obtained for each environmental category (Ghadimi et al. 2019).

In recent years some harmonisation in LCA methodology (Segura-Salazar et al. 2019) has been proposed. In addition, there is a lack of detailed data consistent with the quality requirements of the LCA methodology on the basis of which it would be possible to conduct comparative analyses between individual mining enterprises.

The environmental impact of a mine depends to a large extent on the geological and deposit conditions, the thickness of the deposit, its depth, etc. These aspects determine, for example, the amount of overburden to be removed or the depth of the shaft and the length of galleries to be prepared. Such conditions have a significant impact on the LCA results.

\section{State of the art}

The life cycle phase of fossil fuel extraction is mainly considered in the LCA assessment when evaluating the energy production processes. It is then only one of many unit processes, which contribute to the blurring of miningrelevant results (Ditsele and Awuah-Offei 2012; Singh et al. 2016). LCA covering the extraction phase as one element of the entire life cycle of energy production is far superior to work on focusing exclusively on the coal mining phase and analysing the specific mining conditions and associated environmental impacts, especially those related to surface mining of lignite. The reasons for this may include, among other considerations, problems with the selection of an appropriate functional unit, the limits of the system analysed, or the determination of appropriate impact categories to reflect the significant environmental problems associated with mining. The article focuses on the analysis of lignite mining processes on the basis of data coming from a Polish mine. The technology for opencast lignite mining is noted for its high production efficiency, high level of recovery and lower risk as regards the safety of workers when compared with underground mining systems. However, the need to remove large amounts of overburden to uncover the deposit contributes to a much greater degradation of the landscape. From the analyses of this area available in the literature, the work of Sengül et al. (2016) regarding the LCA of opencast lignite mines based on high quality data from 12 mines in Turkey, including 9 opencast mines, should be quoted. It is also noted in this work that the impacts related to the combustion phase in LCA of coal based production of electricity have so far been the subject of more LCA studies and are better documented. On the basis of the results obtained, it was found that the main environmental impacts are related to the consumption of electricity and diesel oil, waste from the mechanical processing of coal and its washing, as well as belt conveyors used to transport the coal extracted. The analyses show that the proposed alternatives to the dewatering of the mechanical treatment of waste and coal recovery may contribute to a $40 \%$ improvement in the eco-toxicity potential in the water impact category through simple changes in mining practices. Analyses of lignite mining processes in opencast mines are also presented in the work of Mangena and Brent (2006). The authors conduct an LCA assessment of four South African mines producing low and high quality coal, including two opencast and two underground mines. The publication noted that the standard impact categories, i.e. global warming, ozone depletion, human toxicity, water ecotoxicity, acidification, eutrophication, are not sufficient to describe the environmental impact of mineral extraction. The categories of land occupancy, water consumption, energy use and resource depletion have been proposed as the most relevant and equivalent for the LCA analysis of open pit mining. However, there is an ongoing debate among practitioners and scientists about the principles of the different LCA models developed over the last 30 years and the indicators for resource use categories. No compromise has yet been reached on which of them represent the best state-of-the-art (Klinglmair et al. 2014). The most commonly used model is the so-called abiotic depletion potential ADP and it is based on the analysis of current consumption of the reserves (extraction rate, present use) in relation to balanced resources. It is the basis for many LCIA (Life Cycle Impact Assessment) methods currently used (Durucan et al. 2006; Drielsma et al. 2016). However, taking into account the problems of modern mining, in which, apart from environmental and economic aspects, social aspects, rational deposit management and energy security are also taken into account, this indicator is considered insufficient in the process of making investment decisions or regulations concerning raw materials, as it may cause the risk of misinterpretation of the results obtained. In addition to the ADP model, the resource depletion rate in terms of their calorific value (in MJ) is also used as an indicator. However, the method does not assess the environmental impact based on any dependencies (e.g. availability of resources), but only provides information about the amount of fossil fuel extracted in terms of its total energy value.The data presented in the publication show that, in the case of opencast mines, the environmental effects related to the high degree of land degradation reflected in the land use category are significant (Awuah-Offei and Adekpedjou 2011).Factors resulting from geological conditions, such as the ratio of overburden to the amount of coal in the seams that are 
exploited also translate directlyinto this category and into the indicators related to the energy necessary to remove the overburden. Another work dealing with this issue is the one prepared by Gao et al. (2021). In accordance with the issue raised by the authors diversity of land use and the complexity of land use structure, there are severe conflicts in the production-living-ecology space in large-scale opencast coal mine areas, resulting in various degrees of impacts on land use, human settlements and ecological stability of the mining area. As the literature on this issue is is insufficient, especially in terms of predicting these conflicts Authors based on the CLUE-S model and Markov model try measure the current level of land use conflict in opencast coal mining area in China. This research is important in view of modeling of land use in environmental performance of such cases as well as improving the efficiency of land management in mining areas. Land reclamation and land management after the closure of the mine is an important factor, highlighted in many publications referring to mining and its impact on SDG (Sustainable Development Goals) adopted in 2015 by the United Nations General Assembly in the form of a universal, integrated and transformative 2030 Agenda for Sustainable Development, along with a set of 17 SDG and 169 associated targets (Barbosa Reis Monteiro et al. 2019; Endl et al. 2019). However land management after the closure of the mine is an issue which is often overlooked in LCA analysis of opencast mines. A paper that addresses this missing issue is the LCA analysis done by Zhang et al. (2018). The authors concluded that mined land reclamation is an important process in opencast coal mine production; however, it was rarely considered in previous research related with LCA. Therefore, this study attempted to perform a whole environmental impact analysis including land reclamation stage using life cycle assessment (LCA) method. This study could be a useful reference for a deeper understanding of key environmental impacts related to the whole coal production in opencast coal mine. In the literature work focusing not on the entire mining process, but only on its individual aspects can be also find. The analysis prepared by Erkayaoğlu and Demirel (2016) focusing on LCA of transport in surface mining including off-highway mining trucks and belt conveyors. The results of this study revealed that belt conveyors have a greater environmental burden in climate change impact category when compared to the trucks. However trucks have a greater environmental burden in acidication impact category when compared to the belt conveyors.

LCA can also be used as a tool for long-term production planning in surface coal mines, taking into account the environmental conditions of the mine operations. The work presents such an approach presented by Pell et al. (2019). Author stated that LCA are useful to quantify the environmental costs of mining projects, however the application of LCA is often a retrospective environmental measurement of operating mines. Presented in the paper methodology use LCA to generate data that can form an environmental block model of a deposit. These spatially explicit data can then be used as a constraint within longterm mine scheduling simulations.

\section{The Polish situation}

At present the mines extracting lignite in Poland are struggling to expand their current areas of mining activity or to obtain licences to open new opencast operations, despite the fact that for many years the mining output was at a high level (Fig. 1). This is mainly due to the direct environmental impact of opencast operations, increasing environmental awareness of the public and the growing level of social opposition to this issue. The reserves in the existing deposits in Poland and the remaining time of exploitation of the existing lignite power units associated with this are currently predicted to be from ten to a dozen years. Locations of deposits and dedicated power plants are presented on Fig. 2. The opening or expansion of new opencast mines would extend operations to 2044 for Elektrownia Turow and to 2036 for Elektrownia Patnow II. In the case of the Bełchatów Power Plant, which is the largest facility of this type in the world, the current reserves of the Szczercow open pit mine will allow it to operate until 2037. Moreover, the power plant has a plan for a new open pit in Zloczew which will contribute to the possibility of extending this operation for another 39 years. However, due to strong public opposition, this project may not commence operations.

New investments in supercritical lignite-fired units, including $858 \mathrm{MW}$ of capacity commissioned in Belchatow Power Plant in 2011, a 474 MW unit in 2008 in Patnow II Power Plant, and 496 MW in Turow Power Plant expected to be commissioned in 2020, prove that this fuel may still have a significant share in the national power mix over the next few decades of power sector transformation. It is worth noting that the above-mentioned units are currently some of the most modern in the country and their (net) efficiency ranges from $41 \%$ to $43 \%$, which is significantly higher than that of the existing units (including those burning hard coal). Moreover, they meet strict environmental standards, often emitting several times less $\mathrm{SO}_{2}$ and dust than the units currently operating in the country. According to the BREF reference document for large combustion plants (JRC 2017), the Belchatow and Patnow Power Plants will have, additionally, to adapt their units to new emission requirements, which will contribute to further reducing their emissions. Also taking into account 
economic factors, it should be noted that energy produced from lignite is one of the cheapest, calculated per MWh. The sharply growing fees for $\mathrm{CO}_{2}$ emissions in recent years are one of the main tools of the EU decarbonisation policy and significantly reduce the profitability of these installations. At the same time, $\mathrm{CO}_{2}$ sequestration technologies are becoming increasingly available and economically viable, which in the future may result in these units continuing to be stable, economically and environmentally viable generators, operating as the base load of the energy system, and allowing for its transformation towards gas and renewable sources.

The expected lifetime of lignite-fired units, new deposits that it is planned to exploit and high level of public opposition to the associated impact on the environment appear to make it necessary to undertake environmental optimisation of lignite mining and its combustion for energy purposes. While in the case of power plants, we are mainly talking about flue gas purification plants, i.e. CSS, $\mathrm{deNO}_{x}, \mathrm{deSO}_{x}$, mercury removal, in the case of mining and its direct and indirect impact it is necessary to look at the whole process (from the moment of fuel extraction through its transport, processing and use). Identifying in this way all the processes in the chain of supply and production that contribute most to the degradation of the environment could permit the finding of a technological solution for their modernisation or optimisation. This will therefore make it possible to limit the impact of the entire process (the complete chain of supply and production), and not only the node related with energy production and flue gas purification. In this way, the large lignite-fired units envisaged for the country's energy transformation may play an important role in years to come, ensuring the country's energy security and the stability of the electricity supply network, as well as being operated more sustainably and being decommissioned in due course.

Such a holistic approach is possible with the use of environmental impact assessment methods such as LCA. It permits the identification of the environmental weaknesses of the system, for which it is then possible to propose technological solutions designed to reduce this impact. Taking into account that lignite in Poland is still an important source in the national energy system, and the full transformation of the sector towards the exclusion of coal sources may take several decades, the article focuses on the analysis of the lignite mining process and the impact of the quality of the fuel produced on potential emissions from the processes of energy transformation based on it. The analysis covers the whole life cycle of the product and identifies the hot spots in order to propose technological solutions limiting the environmental impacts of the process being analysed.

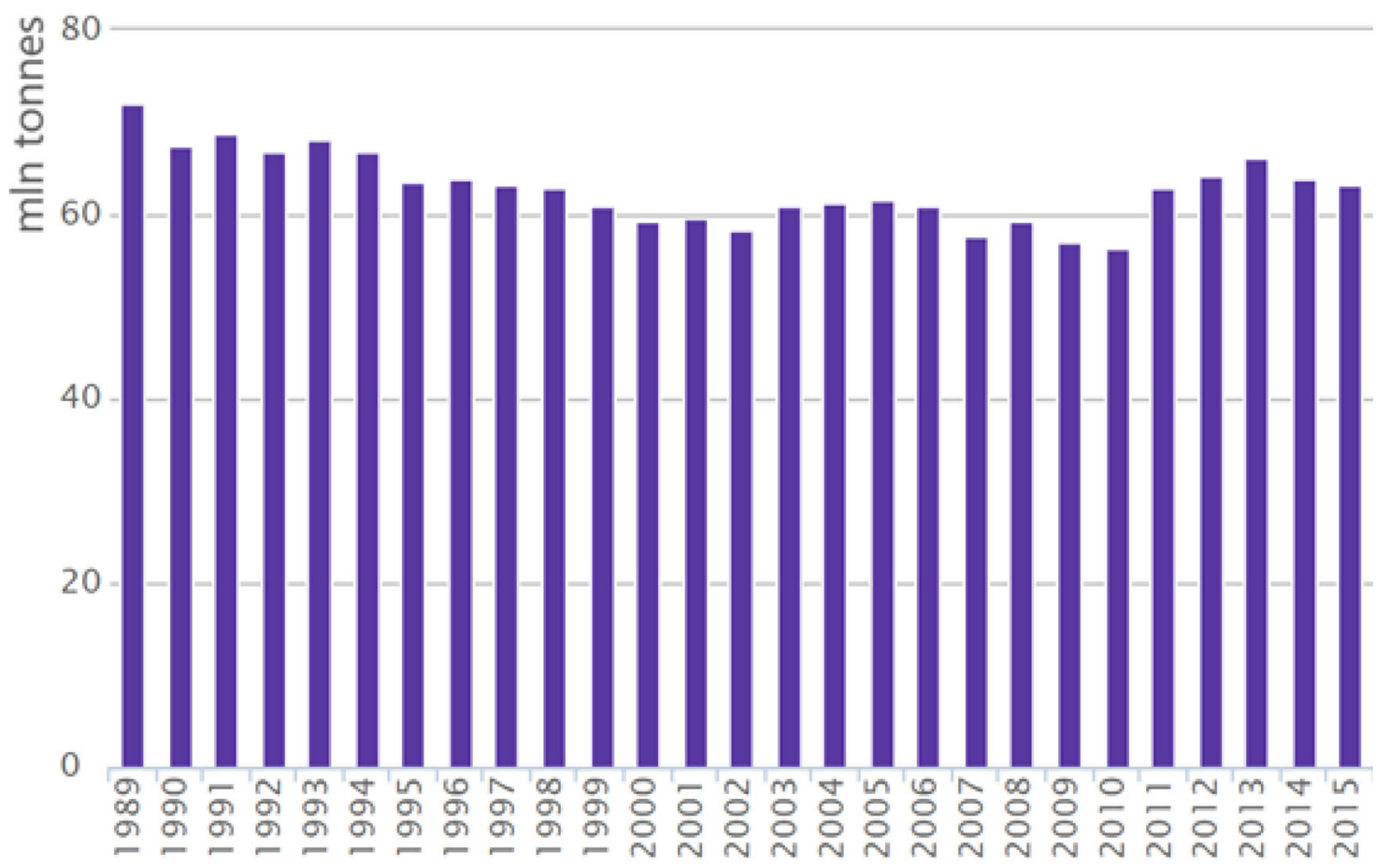

Fig. 1 Lignite production in Poland (1989-2015) (PGI-NRI 2021) 


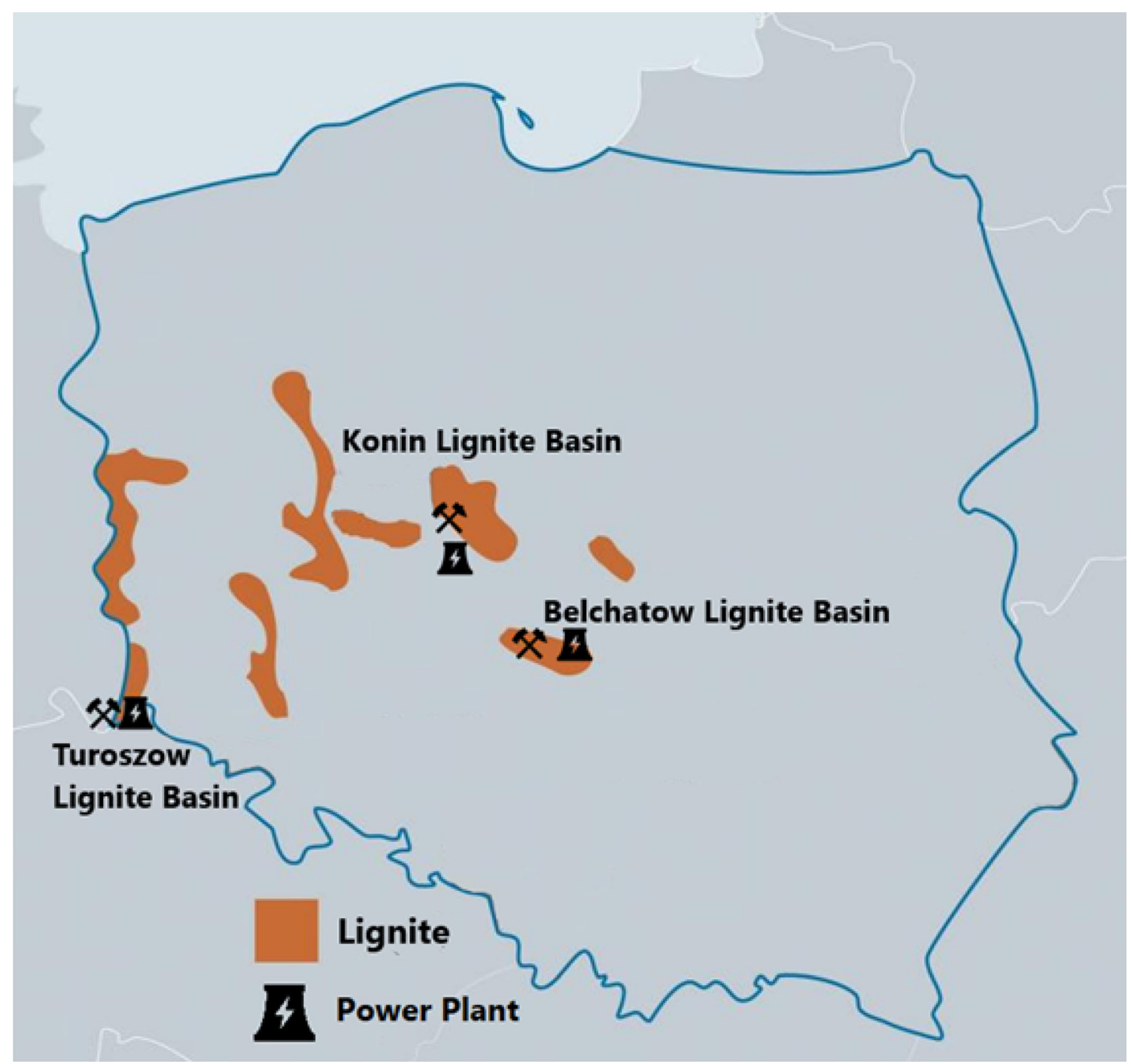

Fig. 2 Map of lignite deposits and power plant in Poland (ATLAS 2015)

\section{Life cycle assessment}

\subsection{Methodology}

The environmental impact analysis was carried out using a model combining LCA, taking into account the principles described in ISO 14040 and 14044, fossil fuel extraction processes with qualitative parameters of the coal produced and emissions of $\mathrm{SO}_{x}, \mathrm{NO}_{x}$ and dust from their combustion processes (Lelek and Kulczycka 2020). The analysis, however, takes into account all phases of the lignite mining and fuel production process (adjusted qualitatively to the current constraints imposed on power plants and other alternative solutions) without taking into account their combustion in the power plant. In the analysis, an attributional analysis (aLCA) approach was used, where the system reflects in detail all areas of activity of the plant being analysed which are carried out in a given place and time (status quo). In such a situation, the allocation approach is applied using physical (mass factor) dependencies. In this way, the environmental impact of the system under analysis on equivalent products is separated out. The LCIA of the mining plant being surveyed was performed using the SimaPro Developer 8.5.0 software and the ILCD 2011 midpoint v.1.05 method.

\subsection{LCI (life cycle inventory)}

In Europe as well as in Poland, the dominant technological system used in lignite mines is a continuous system based on excavators, spreader and belt conveyors is used for both overburden removal and lignite mining (Fig. 3). The overburden is stored on internal or external (outside the excavation) dumping grounds, and the lignite is transported 


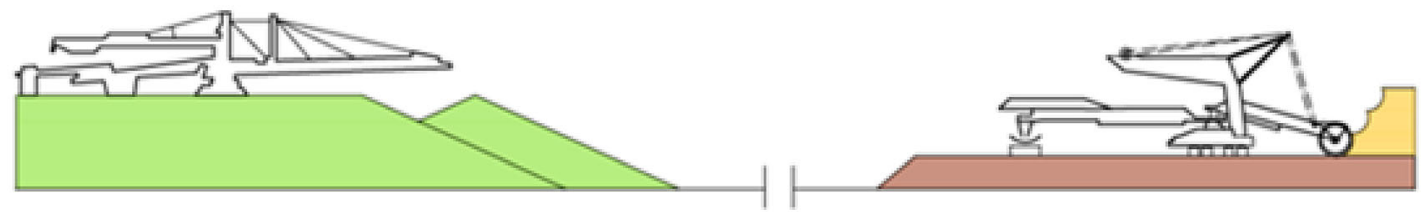

Fig. 3 Scheme of technological system based on excavator - belt conveyor-spreader (Kasztelewicz et al. 2014)

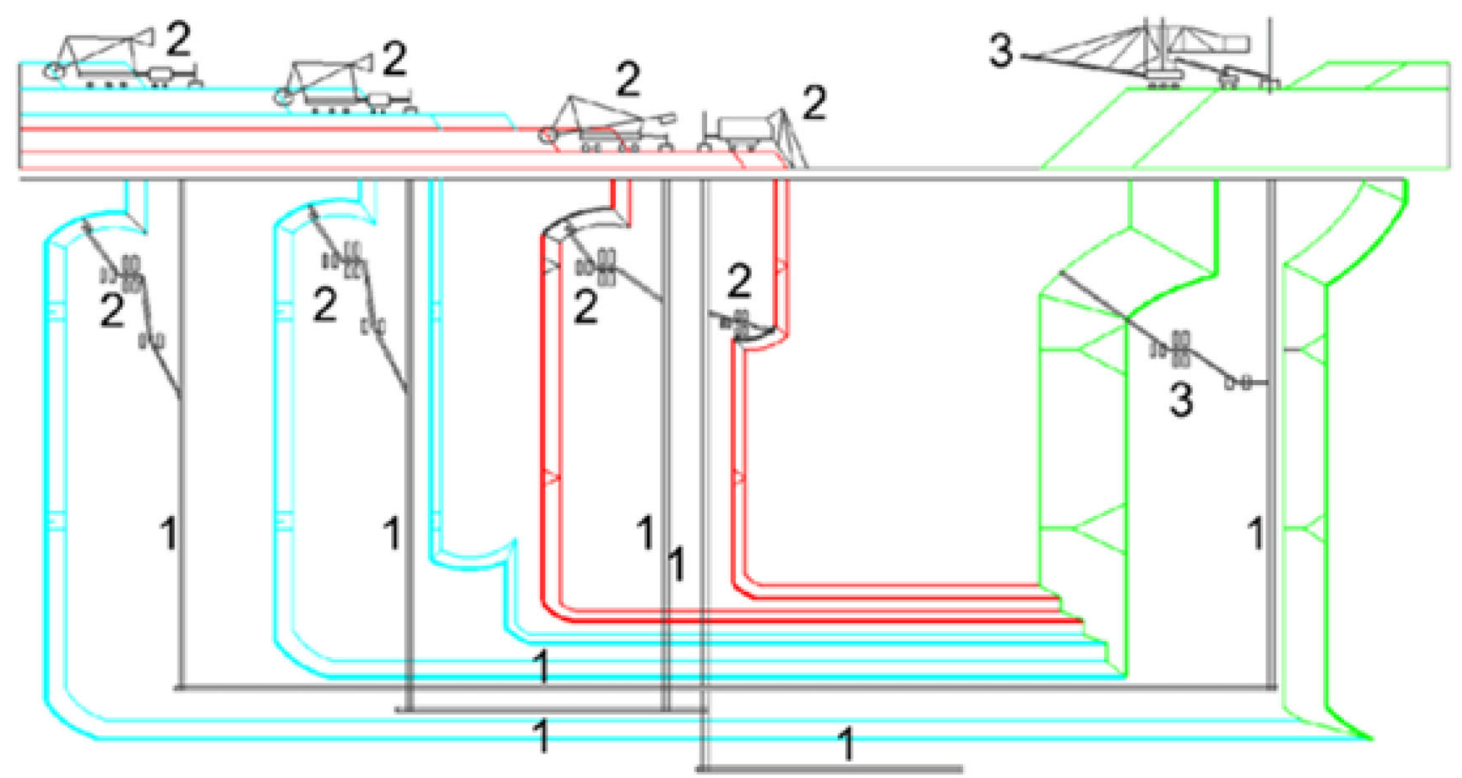

Fig. 4 Schematic cross-section and a plan view of the lignite surface mine: 1-belt conveyor routes, 2-excavators, 3-spreader; blue linesoverburden mining levels, red lines-lignite mining levels, green lines-in-pit dumping level (Kawalec et al. 2020)

by belt conveyor directly to the place of use. A situation diagram of technological systems used in Polish lignite mines is shown in Fig. 4 Inventory data from one of the Polish lignite mines were used for the analysis. The inventory data refers to the annual production portfolio and includes two main elements: input data (streams of materials, energy and fuels entering the process) and output data (streams of materials, energy and fuels coming out of the process). Data were obtained on the basis of the preparation of a questionnaire concerning the mining operations and on the basis of an individual interview. Information related to environmental fees for emissions and for waste generated was also used. The completeness of the data was checked by means of mass-energy balancing at the level of the plant, in accordance with PN-EN ISO 14040:2009, PN-EN ISO 14040:2009. The results obtained showed the differences (\%) between the input and output data of $0.5 \%$. Life cycle data used in the supply chain of consumables, fuels or process steam for the mines were selected from Ecoinvent v3.0 databases and are mostly data representative of the situation at the European level. Data based on the national energy mix were only used for analysis of the electricity used. The analysis omitted the mine's infrastructure and works related to it and preparatory works (making the deposit available). The functional unit adopted for the analysis was the annual production of fuels included in the portfolio, and for comparison purposes auxiliary units were also used in the form of $\mathrm{Mg}$ of coal produced and GJ of energy obtained from the coal that was produced. Inventory data are presented in Table 1 .

In 2015, a total of 42,081 thousand tonnes of lignite was produced in the mine analysed (extraction and processing).

\subsection{Results}

The total cumulative environmental impact, resulting from the annual operation of the mine is $302 \times 10^{3}$ per tonne (Table 2).

The values obtained for the potential environmental impact of the annual production are consistent with the results of the indicator analysis presented in Table 3.

Converted to a rate per GJ of fuel produced, the ratio is $0.89 \times 10^{6}$ per tonne. The demand for electricity accounts for $37.8 \%$. However processes related with overburden management have the highest share in the overall impact accounting for $61.9 \%$ of the cumulative environmental 
Table 1 Inventory data for LCA

\begin{tabular}{|c|c|c|}
\hline Item & Value & Source \\
\hline \multicolumn{3}{|l|}{ Inputs-tehcnosphere flows } \\
\hline Electricity $(\mathrm{kWh})$ & $1,136,340,398.00$ & A \\
\hline Heat energy (GJ) & $223,476.00$ & A \\
\hline Steam (GJ) & $31,153.00$ & A \\
\hline Gasoline (Mg) & 32.38 & $\mathrm{~B}$ \\
\hline Diesel (Mg) & 6103.71 & $\mathrm{~B}$ \\
\hline Fuel oil (Mg) & 541.08 & $\mathrm{~B}$ \\
\hline Grease and chemicals $(\mathrm{Mg})$ & 34.97 & A \\
\hline Explosives $(\mathrm{kg})$ & $1,243,793.00$ & A \\
\hline Ring-directional charges & 253 & $\mathrm{~A}(0.250 \mathrm{~kg} / \mathrm{item})$ \\
\hline TNT Booster stimulators & 16 & A $(0.021 \mathrm{~kg} /$ item \\
\hline Detonators & 36,743 & A $(0.08$ kg/item $)$ \\
\hline Drinking water $\left(\mathrm{m}^{3}\right)$ & $332,954.00$ & $\mathrm{~A}$ \\
\hline \multicolumn{3}{|l|}{ Inputs-elementary flows } \\
\hline Lignite (Mg) & $42,081,000.00$ & A \\
\hline Accompanying fossils (Mg) & $171,205.26$ & A \\
\hline Overburden $\left(\mathrm{m}^{3}\right)$ & $119,734,000.00$ & $\mathrm{D}$ \\
\hline Area occupied (ha) & 8566.00 & A \\
\hline Mine water $\left(\mathrm{m}^{3}\right)$ & $233,689,531.00$ & A \\
\hline \multicolumn{3}{|l|}{ Outputs-technosphere flows } \\
\hline Sewage $\left(\mathrm{m}^{3}\right)$ & $42,040.00$ & A \\
\hline Industrial wastewater $\left(\mathrm{m}^{3}\right)$ & $2,401,964.00$ & A \\
\hline Other wastes $(\mathrm{Mg})$ & $43,604.25$ & A \\
\hline $\begin{array}{l}\text { Lignite (unsorted 0-300 } \\
\text { mm) (Mg) }\end{array}$ & $41,996,838.00$ & A \\
\hline Lignite $(0-40 \mathrm{~mm})(\mathrm{Mg})$ & 84162.00 & A \\
\hline Granite $(\mathrm{Mg})$ & 1856.33 & A \\
\hline Quartzite (Mg) & $64,951.79$ & A \\
\hline Sand and gravel $(\mathrm{Mg})$ & $19,786.20$ & A \\
\hline Lime $(\mathrm{Mg})$ & $77,793.74$ & A \\
\hline Peat $(\mathrm{Mg})$ & 2371.20 & A \\
\hline Humus (Mg) & 4446.00 & A \\
\hline Overburden removed $\left(\mathrm{m}^{3}\right)$ & $119,734,000.00$ & A \\
\hline \multicolumn{3}{|l|}{ Outputs_elementary flows } \\
\hline Mine water discharged $\left(\mathrm{m}^{3}\right)$ & $233,455,635.27$ & A \\
\hline Sewage slurry (kg) & $233,689,531.00$ & A \\
\hline Total dust (Mg) & 0.50 & A \\
\hline Carbon monoxide (Mg) & 0.12 & A \\
\hline Nitrogen oxides (Mg) & 1.76 & A \\
\hline Carbon dioxide $(\mathrm{Mg})$ & 1411.98 & A \\
\hline Aliphatic alcohols (Mg) & 0.51 & A \\
\hline Aliphatic hydrocarbons (Mg) & 4.52 & A \\
\hline
\end{tabular}

$A$ Information (qualitative or quantitative) comes directly from the mine in question included in the analyses without recalculation or transformation, $B$ Information (qualitative or quantitative) based on various indicators, but derived entirely from documents and/or information obtained from the mine, $C$ Information (qualitative or quantitative) based on data from the Marshal's Office concerning the amount of pollutants introduced into the environment, $D$ Information (qualitative or quantitative) based entirely on data from secondary sources (e.g. scientific articles, CSR reports) 
Table 2 Production volumes and potential environmental impact of annual mine operations in 2015

\begin{tabular}{ll}
\hline \multicolumn{1}{c}{ Production volume } & Value \\
\hline Lignite production $(\mathrm{Mg})$ & $41,996,838.00$ \\
Environmental impact $(\mathrm{kPt})$ & 302.00 \\
$\begin{array}{l}\text { Environmental impact per } \mathrm{Mg} \text { of } \\
\quad \text { lignite }\left(\times 10^{6} \text { per tonne }\right)\end{array}$ & 7.18 \\
$\begin{array}{l}\text { Environmental impact per GJ of } \\
\quad \text { lignite }\left(\times 10^{6} \text { per tonne }\right)\end{array}$ & 0.89 \\
\hline
\end{tabular}

Table 3 Indicators of the specific consumption of selected materials, energy and fuels per $\mathrm{Mg}$ of fuel produced for the mine examined

\begin{tabular}{ll}
\hline Indicator & Value \\
\hline Electricity consumption $(\mathrm{kW} \mathrm{h})$ & 27.00 \\
Amount of mine water & 5.54 \\
$\quad$ discharged $\left(\mathrm{m}^{3}\right)$ & \\
Mining area $\left(\mathrm{m}^{2}\right)$ & 1.44 \\
Amount of diesel $(\mathrm{kg})$ & 0.15 \\
Emissions of $\mathrm{CO}_{2}(\mathrm{~kg})$ & $0.46^{*}$ \\
\hline
\end{tabular}

*Due to lack of actual data, the value is calculated indicatively

impact indicator. Excluding the contribution of electricity and overburden, the direct impact is mainly related with lignite deposit depletion, water depletion and land use. From the perspective of mining activities, these are typical environmental impacts. It should be noted that LCA analysis does not show temporally and locally specific environmental effects. Environmental impact modelling, is based on the use of a general cause-and-effect relationship between a given type of environmental emission or intake and the type of impact. This is based on the use of known and scientifically validated relationships in the environmental mechanism. In these models, environmental impacts are assessed by taking into account model-averaged conditions and assuming averaged values of parameters such as population density, land and water area, temperatures, precipitation, ecosystem quality and structure, emissions concentrations, etc. Thus, LCA results are not able to show local effects, as they are "fuzzy" when applied to eg. continental averaged conditions. Analysing the results obtained, several key aspects of modelling were distinguished, i.e:

(1) calorific value-results from the functional equivalence of coal of different calorific values adopted in accordance with the LCA methodology; the results were not only converted into rates per $\mathrm{Mg}$ of coal extracted, but also into rates per GJ of energy,

(2) the volume of electricity consumption coming from the Polish power grid,
(3) the quantity of overburden and waste and manner of its management.

The structure of the environmental impact expressed in percentages of individual impact categories is presented in Table 4.

\subsection{Discussion}

The category of water eutrophication-fresh water, which accounts for $60.23 \%$ of the total impact, is dominant for the plant examined. The category results from the removal of overburden and its moving to internal or external dumping sites, which in consequence causes contamination of groundwater by, among other processes, washing out compounds such as sulphur and other chemicals by precipitation. It should be noted here that the LCA analysis does not show time- and locality- specific environmental effects. Modelling of the environmental impact consists in the use of a general cause and effect relationship between a given type of emission or its retrieval from the environment and the type of impact. The basis for this is the use of known and scientifically confirmed relationships in the environmental mechanism. In these models, the environmental impact is assessed taking into account averaged conditions from a European model and assuming averaged values of parameters such as population density, land area and water area, temperature, precipitation, ecosystem quality and structure, background concentrations, etc. Thus, the LCA results do not have the capacity to show local effects, as they are "fuzzy" due to reference to the conditions based on a continental average. The overburden management impact accounts for $61.9 \%$ of the mine's overall cumulative impact rate and the electricity consumed for another $37.1 \%$.

For the cumulative weighted results of the environmental impact, the following categories should be considered the most important: human health-non-carcinogens, human health-carcinogens, resource depletion-water resources, water eutrophication-fresh water.

Figure 5 and Table 5 present the results of the assessment of what are known as the main environmental impact hot spots, based on weighted impact indicators. According to the results obtained, it can be seen that the demand for electricity, converted into a rate per GJ of coal produced during the year and totalling $3.354 \mathrm{~kW} \mathrm{h/GJ}$, is responsible for $37.8 \%$ of the total impact. The low share of electricity consumption results from the high share of overburden management in the total indicator $(61.9 \%$ of the total cumulative impact index for this mine). Overall, it can be concluded that the above processes are the main hot spots for the plant examined. In order to determine the unit processes which, apart from the ones mentioned above, are 
Table 4 Weighted results of the impact category indicators of annual mine production (2015) both per tonne and per GJ of coal

\begin{tabular}{lll}
\hline Impact category & Value $\left(\times 10^{3}\right)$ & Shared percentage $(\%)$ \\
\hline Climate change & 8.21 & 2.72 \\
Ozone depletion & 0.05 & 0.02 \\
Human toxicity, non-cancer effects & 20.40 & 6.75 \\
Human toxicity, cancer effects & 23.67 & 7.83 \\
Particulate matter & 7.83 & 2.59 \\
Ionising radiation & 0.64 & 0.21 \\
Photochemical ozone formation & 4.95 & 1.64 \\
Acidification & 11.23 & 3.71 \\
Terrestrial eutrophication & 3.22 & 1.06 \\
Freshwater eutrophication & 182.07 & 60.23 \\
Marine eutrophication & 3.30 & 1.09 \\
Freshwater ecotoxicity & 5.11 & 1.69 \\
Land use & -1.36 & -0.45 \\
Water resource depletion & 29.66 & 9.81 \\
Mineral, fossil and renewable resource depletion & 3.31 & 1.09 \\
Total & 302.29 & 100
\end{tabular}

Impact per tonne of coal

Climate change

Ozone depletion

Human toxicity, non-cancer effects

Human toxicity, cancer effects

Particulate matter

Ionising radiation

Photochemical ozone formation

Acidification

Terrestrial eutrophication

Freshwater eutrophication

Marine eutrophication

Freshwater ecotoxicity

0.12

Land use

$-0.03$

Water resource depletion

0.70

Mineral, fossil and renewable resource depletion

Total

7.18

Impact per GJ

Climate change

Ozone depletion

0

Human toxicity, non-cancer effects 0.06

Human toxicity, cancer effects 0.07

Particulate matter 0.02

Ionising radiation

0

Photochemical ozone formation 0.01

Acidification

0.03

Terrestrial eutrophication

0.01

Freshwater eutrophication

Marine eutrophication

Freshwater ecotoxicity

0.02

Land use 
Table 4 continued

\begin{tabular}{lr}
\hline Impact per GJ & Value $\left(\times 10^{6}\right)$ \\
\hline Water resource depletion & 0.09 \\
Mineral, fossil and renewable resource depletion & 0.01 \\
Total & 0.89 \\
\hline
\end{tabular}

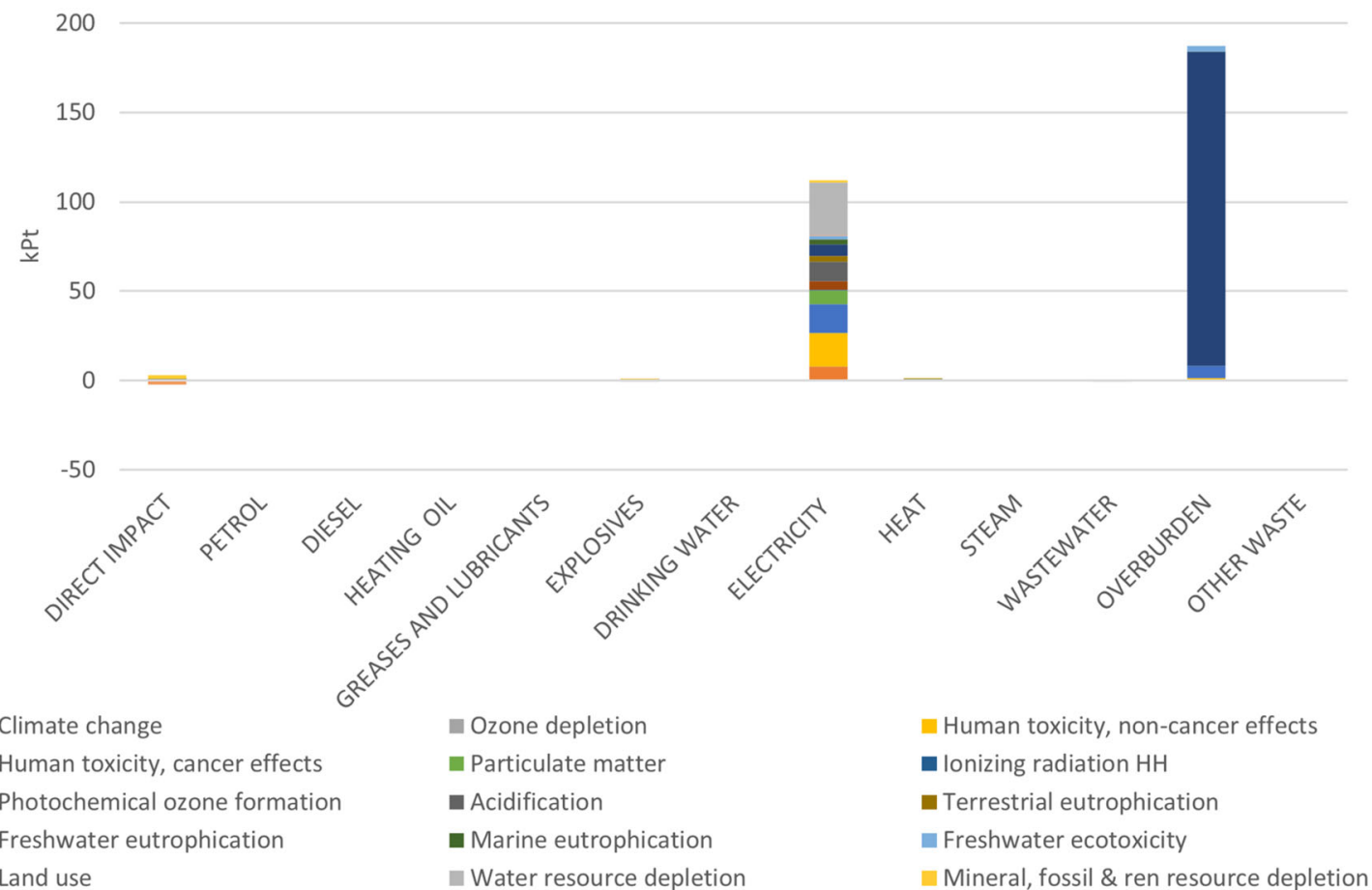

Fig. 5 Weighted analysis results

seen to contribute a significant share of the environmental impact, the results were presented excluding the use of electricity and the necessity to remove the overburden in the next stage of the analysis. Within the framework of the hot spots analysis, and excluding the share of electricity and overburden, the activities of the mine were divided into the following sub-systems:

(1) direct activities (elementary streams)—streams taken directly from the environment (mine waters, mineral resources, land occupancy or transformation), direct emissions to air, water, soil,

(2) processes in the technosphere-material/raw material or energy used in individual technological processes (e.g. explosives, steel, diesel, etc.)

The results of the analysis are presented in Fig. 6 and in a more detailed form in Table 6. If the processes associated with electricity use and the management of the large quantities of overburden are excluded, the calculated impact for its annual operations is reduced to $3.03 \times 10^{3}$ per tonne, of which $65 \%$ is the effect of direct activities. For the plant, a few inventory elements were identified which were considered to be of key importance - coal depletion, water depletion and land use. From the point of view of mining activity, these are typical impacts of a mine on the environment, the dominant impact $(67.79 \%)$ being related to the impact category of mineral, fossil resources (Fig. 6). Furthermore, the land use impact category also has a high share, which is related to the large-scale transformation of the land surface (opencast operations). The recovery of degraded land, which is planned after the closure of the mine, contributes to significant environmental benefits in this category, as shown in Fig. 6 below the $X$ axis and in Table 6 with a negative sign.

Another environmental aspect responsible for a direct impact is associated with the large quantities of mine water pumped out of the mine and its use in technological processes $(13.25 \%$ impact). Figure 6 presents the impact of other technological processes affecting the environment. 


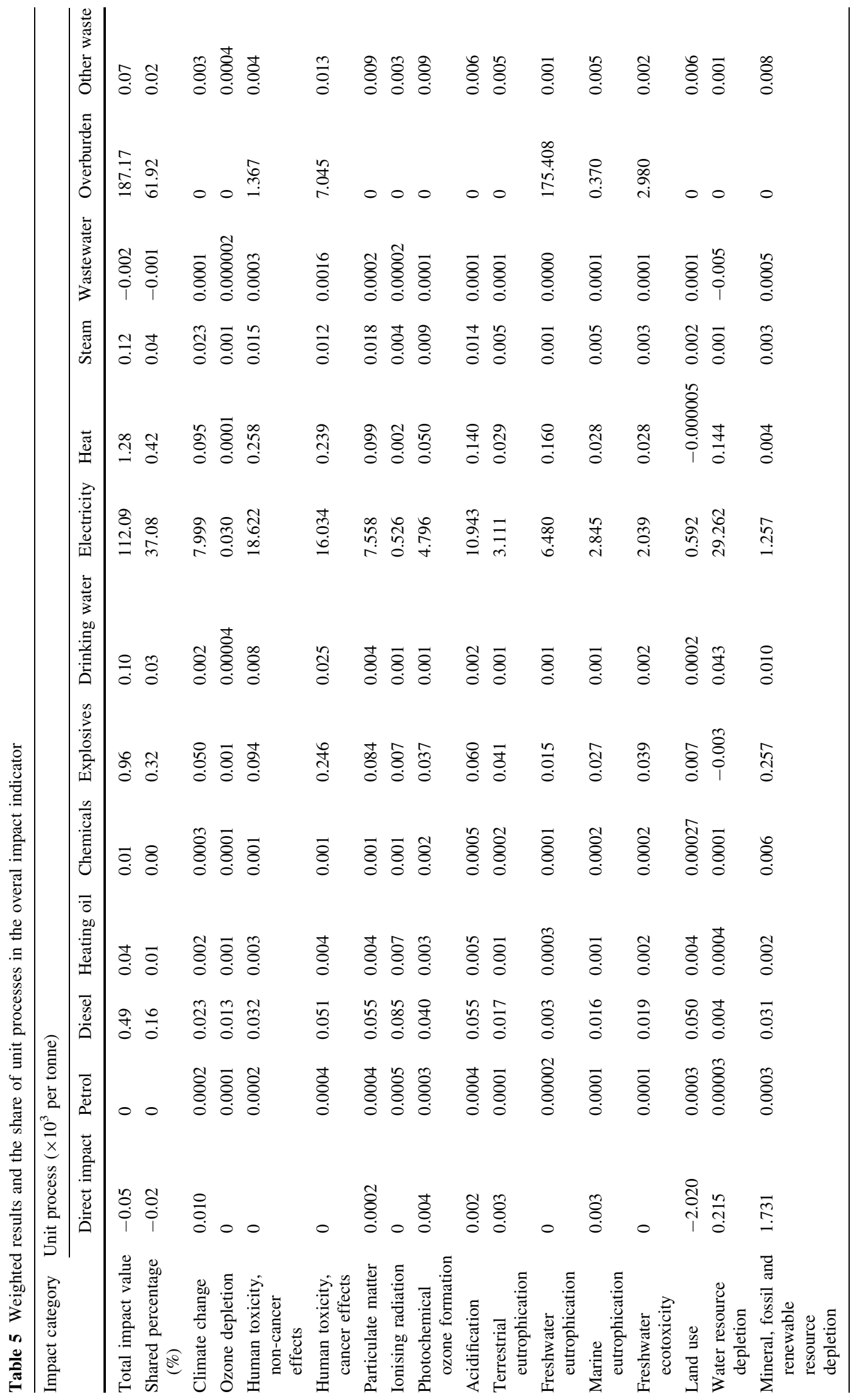




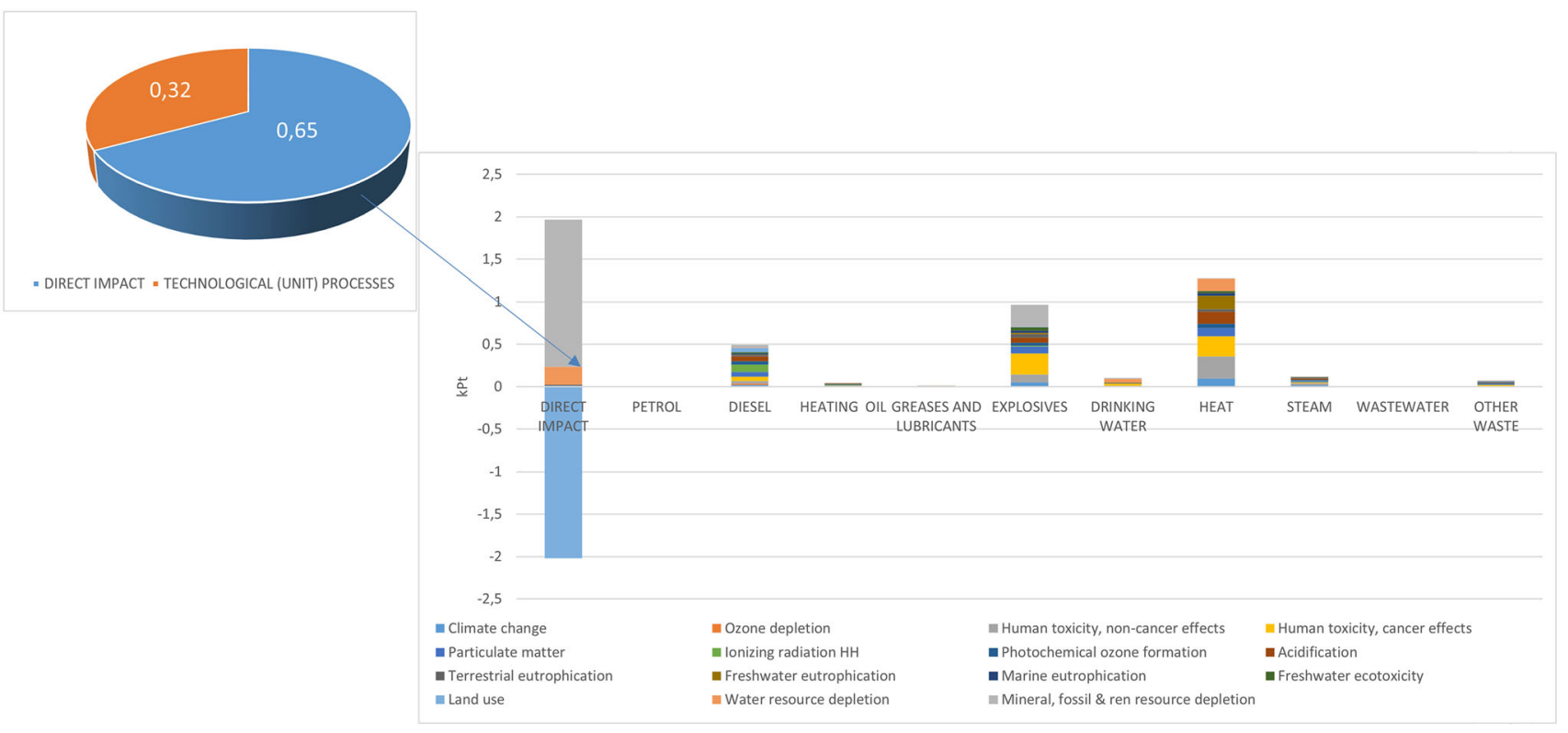

Fig. 6 Weighted results of the analysis (without the use of electricity and the need to remove overburden)

Apart from the direct impact, a significant impact is related to the use of diesel, explosives and heat. These impacts include $16.34 \%\left(0.495 \times 10^{3}\right.$ per tonne), $31.76 \%(0.961$ $\times 10^{3}$ per tonne $)$ and $42.19 \%\left(1.277 \times 10^{3}\right.$ per tonne $)$ of the total indicator. Diesel is mainly burned by trucks transporting part of the overburden and spoil. However, most of the coal extracted and overburden removed is excavated by multi-vessel excavators and transported by electric-powered conveyor belts.

\section{Conclusions}

There is no literature on modelling the impact of mining processes based on the LCA methodology that takes into account the quality of the fuel obtained. The available items underline some methodological inconsistencies, which may be the reason for the small number of LCA studies undertaken in the mining industry. These include, among other issues, problems with the selection of an appropriate functional unit, the limits of the system analysed or the determination of the weight of particular impact categories reflecting the significant environmental problems in mining. In addition, there is a lack of detailed data consistent with the quality requirements of the LCA methodology on the basis of which it would be possible to conduct comparative analyses between individual mining enterprises. The environmental impact of a mine depends to a large extent on the geological and deposit conditions, the thickness of the deposit, its depth, etc. These aspects determine, for example, the amount of overburden to be removed or the depth of the shaft and the length of galleries to be prepared. Such conditions have a significant impact on the LCA results. Analysing the results obtained, several key (hot spot) elements of the lignite mining operations were distinguished for modelling the environmental impact, i.e.: calorific value-results from the functional equivalence of coal of different calorific values adopted in accordance with the LCA methodology; the results were converted not only per $\mathrm{Mg}$ of coal extracted, but also per GJ of energy, the amount of electricity consumptioncoming from the Polish power grid, the manner in which waste is managed and its amount. As a result there is a high sensitivity of the final indicator to changes in these impacts. In general, it can be stated that electricity consumption and the need to manage the overburden are the main hot spots for the study plant. As part of the hot spot analysis, excluding the share of electricity and overburden, most of the environmental impact was generated by direct impact. The process defined as direct impact includes the basic (elementary) streams themselves. Several inventory elements were identified which were considered to be of key importance-coal depletion, water depletion and land use. From the point of view of mining activity, these are typical impacts of a mine on the environment (Bednorz 2011). Generally, the results obtained in the study allowed the unit processes in the life cycle of the fossil fuel extraction processes which contribute the largest share in the overall environmental impact to be identified and prioritised. Due to the fact that the study focused mainly on 


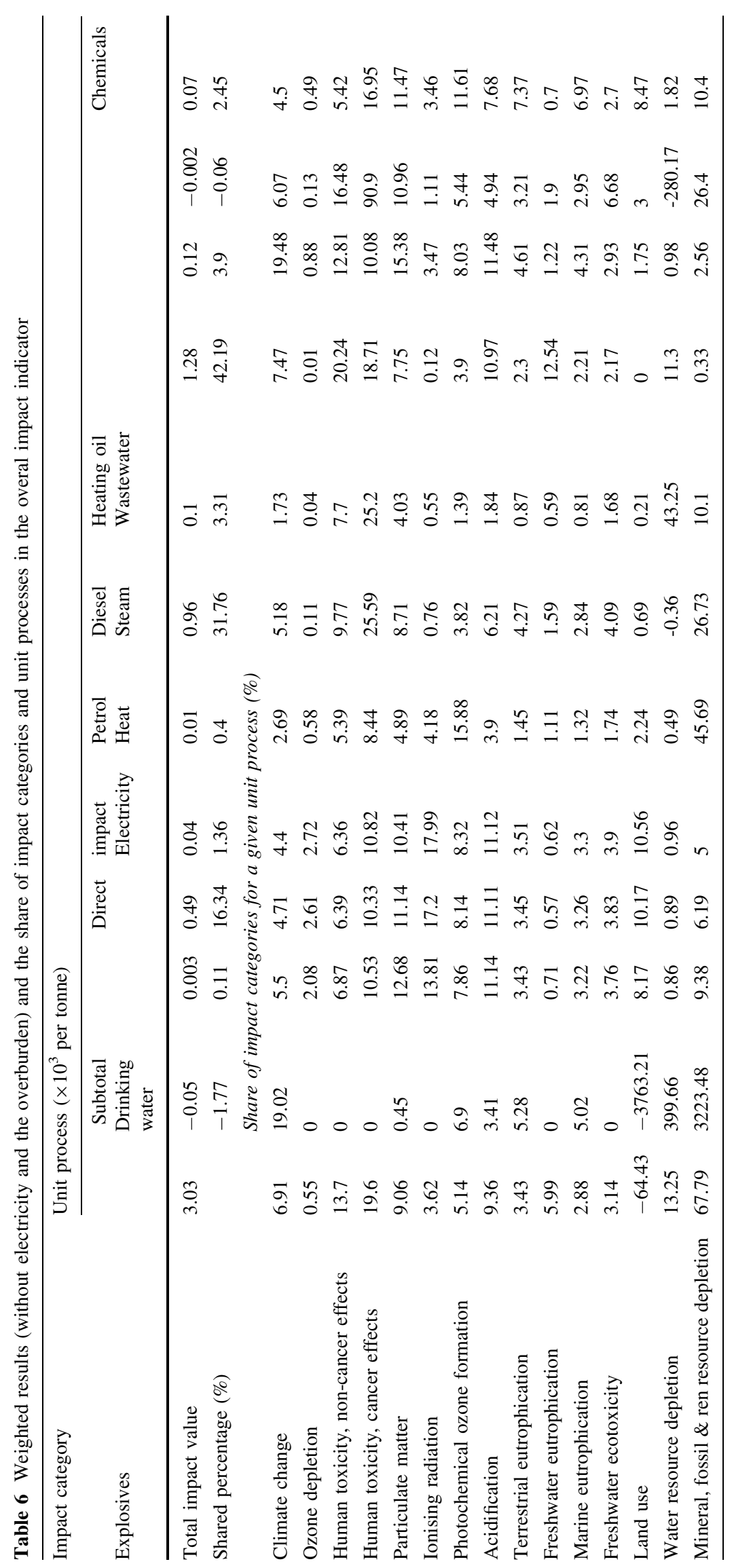


the fossil fuel extraction phase, the hot spots identified concern only this stage of the electricity production life cycle in Poland. Their prioritisation and analysis in terms of alternative technological solutions may be the basis for the introduction of organisational and technical changes aimed at maintaining the optimum quality of the environment of these processes.

\section{Declarations}

Conflict of interest The authors declare that they have no conflict of interest.

Open Access This article is licensed under a Creative Commons Attribution 4.0 International License, which permits use, sharing, adaptation, distribution and reproduction in any medium or format, as long as you give appropriate credit to the original author(s) and the source, provide a link to the Creative Commons licence, and indicate if changes were made. The images or other third party material in this article are included in the article's Creative Commons licence, unless indicated otherwise in a credit line to the material. If material is not included in the article's Creative Commons licence and your intended use is not permitted by statutory regulation or exceeds the permitted use, you will need to obtain permission directly from the copyright holder. To view a copy of this licence, visit http://creativecommons. org/licenses/by/4.0/.

\section{References}

Aguirre-Villegas HA, Benson CH (2017) Case history of environmental impacts of an Indonesian coal supply chain. J Clean Prod 157:47-56. https://doi.org/10.1016/j.jclepro.2017.03.232

ATLAS WEGLA (2015) Fundation Heinricha Bölla, The Institute for Sustainable Development, Bund für Umwelt und Naturschutz Deutschland. https://pl.boell.org/pl/atlas-wegla-dane-i-fakty-oglobalnym-paliwie. Accessed 10 May 2021. Based on license Creative Commons (CC BY-SA 3.0 DE), with additional changes. https://creativecommons.org/licenses/by-sa/3.0/pl/deed.en

Awuah-Offei K, Adekpedjou A (2011) Application of life cycle assessment in the mining industry. Int $\mathrm{J}$ Life Cycle 16:82-89. https://doi.org/10.1007/s11367-010-0246-6

Barbosa Reis Monteiro N, Aparecida da Silva E, Machado Moita Neto J (2019) Sustainable development goals in mining. J Clean Prod 228:509-520. https://doi.org/10.1016/j.jclepro.2019.04.332

Bednorz J (2011) Społeczno-ekologiczne skutki eksploatacji wegla kamiennego w Polsce. Górnictwo i Geologia. https://www.polsl. pl/Wydzialy/RG/Wydawnictwa/Documents/kwartal/6_4_1.pdf. Accessed 29 Aug 2020

Burchart-Korol D, Fugiel A, Czaplicka-Kolarz K, Turek M (2016) Model of environmental life cycle assessment for coal mining operations. Sci Total Environ. https://doi.org/10.1016/j.scito tenv.2016.03.202

IEA (2019) Coal Information. Statistics report. https://www.iea.org/ reports/coal-information-overview. Accessed 29 Aug 2020

European Commission (2017) Press release: No region left behind: launch of the Platform for Coal Regions in Transition. https://ec. europa.eu/energy/events/conference-coal-regions-transition-plat form_en?redir=1. Accessed 29 Aug 2020

Ditsele O, Awuah-Offei K (2012) Effect of mine characteristics on life cycle impacts of US surface coal mining. Int J Life Cycle 17:287-294. https://doi.org/10.1007/s11367-011-0354-y
Drielsma JA, Russell-Vaccari AJ, Drnek T, Brady T, Weihed P, Mistry M, Perez Simbor L (2016) Mineral resources in life cycle impact assessment-dening the path forward. Int $\mathrm{J}$ Life Cycle Assess 21:85-105. https://doi.org/10.1007/s11367-015-1006-4

Durucan S, Korre A, Munoz-Melendez G (2006) Mining life cycle modelling: a cradle-to-gate approach to environmental management in the minerals industry. J Clean Prod 14:1057-1070. https://doi.org/10.1016/j.jclepro.2004.12.021

Erkayaoğlu M, Demirel N (2016) A comparative life cycle assessment of material handling systems for sustainable mining. J Environ Manag 174:1-6

Endl A, Tost M, Hitch M, Moser P, Feiel S (2019) Europe's mining innovation trends and their contribution to the sustainable development goals: blind spots and strong points. Resour Policy. https://doi.org/10.1016/j.resourpol.2019.101440

The European Parliament (2019) Climate change, European Parliament resolution of 14 March 2019 on climate change-a European strategic long-term vision for a prosperous, modern, competitive and climate neutral economy in accordance with the Paris Agreement (2019/2582(RSP)). https://www.europarl. europa.eu/doceo/document/TA-8-2019-0217_EN.htm. Accessed 29 Aug 2020

IEA (2020) Energy Policy Review. Country report - June 2020. European Union. https://www.iea.org/reports/european-union2020. Accessed 29 Aug 2020

Gao Y, Wang J, Zhang M, Li S (2021) Measurement and prediction of land use conflict in an opencast mining area. Resour Policy 71:101999. https://doi.org/10.1016/j.resourpol.2021.101999

Ghadimi P, Wang C, Hossein Azadnia A, Lim MK, Sutherland JW (2019) Life cycle-based environmental performance indicator for the coal-to-energy supply chain: a Chinese case application. Resour Conserv Recycl 147:28-38. https://doi.org/10.1016/j. resconrec.2019.04.021

Guimarães da Silva M, Costa Muniz AR, Hoffmann R, Luz Lisbô AC (2018) Impact of greenhouse gases on surface coal mining in Brazil. J Clean Prod 193:206-216. https://doi.org/10.1016/j. jclepro.2018.05.076

JRC (2017) Science for Policy Report. Best available techniques (BAT) reference document for large combustion plants. European Commission. https://ec.europa.eu/jrc/en/publication/eurscientific-and-technical-research-reports/best-available-techni ques-bat-reference-document-large-combustion-plants-indus trial. Accessed 29 Aug 2020

Ju Y, Zhu Y, Xie H, Nie X, Zhang Y, Lu C, Gao F (2019) Fluidized mining and in-situ transformation of deep underground coal resources: a novel approach to ensuring safe, environmentally friendly, low-carbon, and clean utilisation. Int $\mathrm{J}$ Coal Sci Technol 6:184-196. https://doi.org/10.1007/s40789-019-0258-1

Kawalec W, Suchorab N, Konieczna-Fuławka M, Krol R (2020) Specific energy consumption of a belt conveyor system in a continuous surface mine. Energies 13(19):5214. https://doi.org/ $10.3390 /$ en 13195214

Kasztelewicz Z, Zajaczkowski M, Sikora M, Patyk M (2014) Surface mining systems in lignite mines around the world. Przeglad Gorniczy 10(70):85-89

Klinglmair M, Sala S, Brandao M (2014) Assessing resource depletion in LCA: a review of methods and methodological issues. Int J Life Cycle Assess 19:580-592. https://doi.org/10. 1007/s11367-013-0650-9

Kopacz M, Kryzia D, Kryzia K (2017) Assessment of sustainable development of hard coal mining industry in Poland with use of bootstrap sampling and copula-based Monte Carlo simulation. J Clean Prod 159(15):359-373. https://doi.org/10.1016/j.jclepro. 2017.05.038 
Lelek L, Kulczycka J (2020) Life cycle modelling of the impact of coal quality on emissions from energy generation. Energies 13(6):1-11. https://doi.org/10.3390/en13061515

Mangena SJ, Brent AC (2006) Application of a life cycle impact assessment framework to evaluate and compare environmental performances with economic values of supplied coal products. J Clean Prod 14:1071-1084. https://doi.org/10.1016/j.jclepro. 2004.04.012

Pell R, Tijsseling L, Palmer LW, Glass HJ, Yan X, Wall F, Zeng X, Li J (2019) Environmental optimisation of mine scheduling through life cycle assessment integration. Resour, Conserv Recycl 142:267-276

Segura-Salazar J, Mariano Lima F, Marcelo Tavares L (2019) Life cycle assessment in the minerals industry: current practice, harmonization efforts, and potential improvement through the integration with process simulation. J Clean Prod 232:174-192. https://doi.org/10.1016/j.jclepro.2019.05.318

Sengül H, Bayrak F, Köksal M, Ünver B (2016) A cradle to gate life cycle assessment of Turkish lignite used for electricity generation with site-specic data. J Clean Prod 129:478-490. https:// doi.org/10.1016/j.jclepro.2016.04.025

Singh U, Sharma N, Mahapatra SS (2016) Environmental life cycle assessment of Indian coal-fired power plants. Int J Coal Sci Technol 3(2):215-225. https://doi.org/10.1007/s40789-0160136-Z

Council of the European Union (2020) Submission by Croatia and the European Commission on behalf of the European Union and its Member States. Subject: long-term low greenhouse gas emission develop. https://unfccc.int/sites/default/files/resource/HR-03-06$2020 \% 20$ EU\%20Submission\%20on\%20Long\%20term\%20strat egy.pdf. Accessed 29 Aug 2020

European Commission, EU Science Hub, Sustainable production and consumption (2020). https://ec.europa.eu/jrc/en/researchtopic/sustainable-production-and-consumption. Accessed 29 August 2020

Wang C, Mu D (2014) An LCA study of an electricity coal supply chain. J Ind Eng Manag 7(1):311-335. https://www.jiem.org/ index.php/jiem/article/view/1053>

PGI-NRI (2021) Wegiel Brunatny. Informacje ogolne i wystepowanie. http://geoportal.pgi.gov.pl/surowce/energetyczne/ wegiel-brunatny. Accessed 10 May 2021

IEA (2019) World Energy Outlook. https://www.iea.org/reports/ world-energy-outlook-2019. Accessed 29 August 2020

Xu J (2013) Research on carbon emissions measurement of coalenergy chain based on life-cycle assessment method. Appl Mech Mater 367:333-338

Yu S, Yi MW, Guo H, Ding L (2014) Carbon emission coefficient measurement of the coal-to-power energy chain in China. Appl Energy 114:290-300. https://doi.org/10.1016/j.apenergy.2013. 09.062

Zhang L, Wang J, Feng Y (2018) Life cycle assessment of opencast coal mine production: a case study in Yimin mining area in China. Environ Sci Pollut Res 25:8475-8486. https://doi.org/10. 1007/s11356-017-1169-6 